Transformational Leadership In The Middle Of Plurality And Global Challenges

\title{
TRANSFORMATIONAL LEADERSHIP IN THE MIDDLE OF PLURALITY AND GLOBAL CHALLENGES
}

\author{
Syafhendry, Setyo Utomo \\ Islamic University of Riau, Departement of Government Science, Faculty of Social and \\ Political Sciences / Jl. Kaharuddin Nst Number 113, Pekanbaru, Indonesia \\ syafhendry.ip@soc.uir.ac.id; setyoutomo993@gmail.com
}

\begin{abstract}
Leadership is an important factor, in order to meet public demands and aspirations. Leadership is the key word for the realization of justice, prosperity and equitable development amid a pluralistic society. Especially in the midst of a multidimensional crisis that has accumulated in the economic crisis experienced by the Indonesian people since the 1998 crisis has spawned a variety of public problems that have until now been fully resolved. Efforts to organize and overcome multidimensional crises amid global challenges will be quickly carried out if the transformation process in the community is able to produce good leadership at all levels of government, both central and regional. As a large pluralistic nation with all its problems, this nation needs political leadership that has a high commitment to solve various problems in the community. In the era of democratization, it is hoped that the leadership process will be more open and promising transformation and change in the community. Through leadership among the community, both through political parties, community organizations (such as NU, Muhammadiah) and leadership processes born of various organs in the community are expected to produce credible leaders and have a strong vision to solve various problems in the community. Where leadership is not interpreted as limited to power, but leadership really promises to improve and change amid the community.
\end{abstract}

Keywords: Leadership, governance, global challenges 
Proceeding ICOGISS 2019

Page 690-697. ISBN: 978-602-6 988-75-1

Web Jurnal Online: jurnal.unmuhjember.ac.id

By: Syafhendry; Setyo Utomo

Transformational Leadership In The Middle Of Plurality And Global Challenges

\section{Introduction}

As a large pluralistic nation with a variety of diversity, both race, ethnicity, religion and political ideology, Indonesia has both advantages and challenges. On the one hand, the existing pluralism can be a strength for Indonesia, at the same time it can be a threat to the sustainability of a large and diverse nation. To manage large and diverse resources, of course strong leadership is needed and able to manage diversity that exists in the community. So that community leaders are able to stand above all groups, where the policies reflect represent all groups and elements that exist in the community. In order to create a strong spirit and unity from all elements and groups in the community, to have the same view to build this nation from various challenges and common problems. Amid the plurality of societies that exist in the Indonesian nation, at least we have two major challenges, both internal (diversity factors) and external challenges amidst the rapid changes in social change that are being felt globally.

The prolonged economic crisis has given rise to a multidimensional crisis for this nation. From the economic crisis has given rise to various problems and crises amid the community, ranging from poverty, unemployment, uneven development, the strengthening of radicalism and intolerance in the community, environmental destruction and problems of corruption in the body of government that continues to haunt this country. From the various problems above, it needs at least a rapid response to immediately bring this nation out of these multidimensional crises. The leadership factor in my opinion is a keyword so that we are not kept hostage by the various problems above. In the midst of the diversity of the community and the emergence of global challenges needed transformational leaders, who are able to understand the breath of diversity and understand various global problems and challenges. Transformational leadership here is required to be able to map and analyze the various potentials possessed by the Indonesian people, both the potential of culture, knowledge and the power of ideology which are expected to be able to solve various major problems in the community. In transformational leadership, we need a leader who is able to motivate and mobilize all elements and strengths of the nation, to fight together to resolve the various crises that have occurred in this nation. As Bass in Swandari (2003) defines transformational leadership is leadership that has the power to move subordinates in certain ways. So from here it is hoped that respect and militancy will emerge from all structures within the government and society, to join together in seeking common goals and aspirations, while at the same time solving various problems faced by this nation. Furthermore, pmcounseling (2011) states that, transformational leadership is a type of leadership style that leads to positive change to its followers. Transfionalional leaders are generally energetic, enthusiastic and passionate. This jnis leader not only focuses on the leadership process, but besides they are involved in the leadership process, while focusing on helping each member or group to succeed in solving problems.

From various expert explanations about the concept of transformational leadership above, the transformational leadership model is very appropriate to be applied in Indonesia, as a large nation that has the complexity of problems and diversity factors that exist in its society. With the differences that are not made as something negative that has the potential to divide, but with differences and diversity possessed by this nation, it 
is expected to be able to become a force and create positive energy for the community to build a power that is able to solve the problems behind the plurality of society born due to the system of globalization.

\section{Complexity of Problems Amid Diversity}

As a large nation that has a diversity of both tribes, cultures, beliefs and political ideologies, the Indonesian nation reflects a multicultuiral society, which consists of the various pluralities above. Where togetherness and the spirit of unity are still held in high esteem by various groups and individuals who want to continue the upright State of the Republic of Indonesia (NKRI) which has agreed and bound itself as a nation from Sabang-Merauke. Although this is not without testing, various problems that disturb and want to disturb the spirit of unity often come and approach this nation in its journey, but this nation is able to pass various tests that try to divide behind the diversity of this nation. So that the Indonesian people can be regarded as a multicultural society, capable of side by side with one another to stand as a nation.

Furthermore, the picture about multicultural, can refer to the view of C.W. Watson (1998) in his book, Multiculutralism, which according to him talks about the people of the State, nation, region, even limited geographical locations such as cities or schools, which consist of people who have cultures that differ in equality. In essence the multicultural society is a society consisting of various kinds of tribes, each of which has a different cultural structure. In this case the multicultural society is not homogeneous, on the contrary reflects a heterogeneous society where the pattern of social relations between individuals is tolerant and there is recognition of the necessity of a reality to coexist peacefully with one another with differences that exist in each social and political entity. So, in a multicultural society there is a potential for vertical and horizontal conflicts, if differences and diversity exist in the community, there is not a good awareness to coexist with one group / group with another. Many countries in the world have shown that horizontal and vertical conflicts have led to wars involving ethnic, racial, even political and religious ideologies, both among religious groups such as those in India, Sri Lanka, Bosnia, Yugoslavia, Lebanon, the Union The Soviets, even those that have recently occurred in the Middle East, such as in Syria and Egypt.

The Indonesian nation was not spared from conflicts that were born due to friction from differences that existed in the community. A number of conflicts in various regions, such as in Ambon which were born as a result of political conflict wrapped in involving religious sentiments, ethnic conflicts in Sampit, Poso, show that differences and diversity in potential communities give rise to conflict among communities, if not properly anticipated. Dark history has also come to this nation, with the birth of the 30 September Indonesian Communist Party (G30SPKI) movement, which resulted from ideological and political differences when efforts to replace the State ideology system based on Pancasila would be replaced by communist ideology by the Indonesian Communist Party (PKI) through a coup attempt against legitimate and legitimate power under the Soekarno government. 
Proceeding ICOGISS 2019

Page 690-697. ISBN: 978-602-6 988-75-1

Web Jurnal Online: jurnal.unmuhjember.ac.id

By: Syafhendry; Setyo Utomo

Transformational Leadership In The Middle Of Plurality And Global Challenges

Even today the movement strengthens and propaganda in the community who want to replace the State ideology system (Pancasila) with the Caliphate ideology system, such as that carried out by Hizb ut-Tahrir Indonesia (HTI) which continues to campaign the khilafah ideology among the people. At the same time it shows the symptom of the strengthening of ethnocentrism in the community, in addressing various national dynamics, especially in the political dynamics that have occurred lately. Speeches of hatred and views that tend to demean other groups and consider their groups to be the best, these days have been strengthened in debates and discourses in the public sphere, both through social media and open debates that are often displayed by the mass media. This whole attitude is reflected both in political and social social movements which lead to social tensions in the community. This certainly can disrupt the process of consolidation and strengthening of Pancasila ideology carried out by the government and various elements of society, to build a spirit of unity and strengthen the spirit of nationality as a capital to carry out development and strengthening communities in various sectors. If the attitude of ethnocentrism and the practice of speech hate continues to be left and not immediately understood by all elements of the nation, this will give birth to social tensions which lead to the condition of social disintegration in the community.

\section{Challenges and Globalization Problems}

Globalization in addition to giving birth to opportunities as well as bringing a threat to the sustainability of world countries, including Indonesia. But the presence of globalization is a necessity, a thing that is impossible to avoid anymore. Indonesia as a developing country is demanded to be ready to compete in facing unbalanced global competition, especially in the economic field. The onslaught of foreign products into Indonesia is increasingly massive and flooding the domestic market. So that the readiness of the Indonesian people to face global economic competition must surely be done, so that our nation is not only a consumer, but can become a new player as a producer in the international market.

The presence of globalization in addition to bringing opportunities also presents a serious threat, including threatening the moral values and character of society. The shift in moral values and character is caused by the increasingly massive flow of uncontrolled information due to information technology innovation. Like the phenomenon of social media lately, it has become a new trend and behavior of people, who tend to use social media for things that are negative compared to doing positive things. Various speeches of hatred and mutual dissemination of information that cannot be justified (hoaxes) become a new trend in the behavior of social media actors. Whether it is realized or not, this has shifted the moral values and character of the Indonesian people who tend to be polite, have high tolerance, as if they have changed into fond behavior to blaspheme each other and build hostility towards their fellow citizens.

In the political aspect at least, globalization seems to be able to anesthetize the Indonesian people, that liberalism can bring progress and prosperity. This if not carefully addressed has the potential to shift attitudes and views based on the Pancasila ideology into ideology liberalism, in the practice of the life of the nation and state. 
While the impact of globalization in the economic sector is, the fading of a sense of love for domestic products and more love for goods or products from outside which are increasingly flooding the market in the country. If not anticipated, this will eliminate some domestic companies, both small and large companies, which of course will be detrimental to the economic sector in the community. If this continues to occur, it will create social and economic disparities that are increasingly widening among the people and between nations, because of the process of free competition in economic globalization. This can lead to conflict that can disrupt the survival of a nation, and increase the number of poverty and unemployment in the community.

The emergence of individualism that gives birth to ignorance of fellow citizens is another negative side of the influence of globalization, which has dissolved a sense of social solidarity and waning the bonds of kinship in the cultural system of our society. Slowly the values in the community that were once very strong based on traditional values and religion have shifted towards modern values born from the womb of globalization. The attitude of consumerism and hedonism that influences the lifestyle of the young generation now is a series of adverse effects of globalization on the character and mental development of society, due to the influence of globalization.

Facing the negative impacts of globalization that are quite complex, we inevitably have to find a formula to fortify this nation from the adverse effects of globalization. The attitude and competitive value possessed of the nation's potential must be built and reemerged to strengthen the identity of society and the nation, so that we have readiness in facing globalization. Traditional and religious values are one of the capital and positive energies to build the character and mentality of the community, so that they are not trapped in the trap of globalizing modernization. The spirit of togetherness, mutual cooperation and mutual love for one another are, values and moral messages that have been taught both in the system of values of our beliefs as a nation of God, which has become one with traditions that have been rooted in the culture of society. We must return to the values of religion and tradition to strengthen character while building a mentality that is ready to face the various effects of globalization.

\section{Transformational Leadership As an Alternative Solution}

Seeing the various complexities of problems faced by this nation, both from within and as a result of the wave of globalization requires transformational leadership that is strong, visionary and understands the fundamental problems faced by this nation. This is in line with the opinion of Kendra (2013) which states that transformational leaders are someone who controls the situation by conveying a clear vision of group goals, passion in work and the ability to make group members feel recharged and energized. In the practice of the life of the nation and state, where the society is a pluralistic society, a leader is required to understand the breath of his diverse community, both race, ethnicity and religion. So that with a clear vision and mastery of problems faced by the nation, a leader can always bring energy and a positive outlook to move his community into a developed society. Furthermore, transformational leadership is explained by Burns in Kendra (2013), that transformational leadership can be seen when leaders and followers create each other to enhance morale and motivate through the 
strength of their vision and personality, transformational leaders are able to inspire followers to change expectations, perception and motivation to work towards a common goal.

\section{Charismatic}

The prerequisites needed in transformational leadership are as follows:

The traditional view still sees that charisma is only possessed by those great leaders of world leaders. In its course this view develops. That writing proves that charisma can be owned by the lower level leaders of an organization (Hartiti, 2013). The charismatic leader has characteristics that show the strength of his vision, abilities and expertise in actions that better reflect the attitudes of prioritizing the interests of others (society) compared to personal interests. So that naturally charismatic leaders are often used as role models and become role models for followers or subordinates. In addition, leaders are said to be charismatic because leaders can motivate subordinates to put forth hard work because of their love for their leaders (Hartiti, 2013).

\section{Idealists}

Transformational leaders become role models and inspire their subordinates (Kendra, 2013). Followers here have trust, trust and a high attitude towards respecting their leaders. So the followers are inspired to follow and follow the values held by the leader. This model leader seeks to influence his subordinates through direct communication by conveying the importance of values, assumptions, commitments and beliefs and having the determination to achieve goals by considering the moral and ethical consequences of each decision made.

\section{Motivational inspiration}

Transformational leaders have a clear vision that they are able to articulate a value and belief in followers. Leaders here help increase followers' passion and motivate to achieve goals (Kendra, 2013)

\section{Intellectual stimulation}

The leader encourages subordinates to rethink work methods and find new ways of working in completing their duties and responsibilities.

\section{Individual Consideration}

This type of leader has more attention to his followers or subordinates. By treating their followers or subordinates as treating them as intact individuals and respecting their caring attitude toward the organization. 
Proceeding ICOGISS 2019

Page 690-697. ISBN: 978-602-6 988-75-1

Web Jurnal Online: jurnal.unmuhjember.ac.id

By: Syafhendry; Setyo Utomo

Transformational Leadership In The Middle Of Plurality And Global Challenges

\section{Conclusion}

After the government transition from the New Order government to a more open and democratic Reformasi government system, problems related to plurality in the community began to occur and emerge. This multicultural problem must be anticipated by leadership that enlightens pluralistic societies, so that there is a process of maturing people's thinking in the process of nation and state. If this diversity factor cannot be managed and managed properly it will create a serious threat to the sustainability of the Indonesian nation. Challenges in the nation and state at the same time today also come due to the wave of globalization modernization which has produced rapid changes in various fields. Where globalization also brings a variety of separate problems, especially related to justice and the problem of poverty. Transformational leadership is seen as an alternative solution to solve various challenges and problems related to pluralism and the challenges of globalization. 
Proceeding ICOGISS 2019

Page 690-697. ISBN: 978-602-6 988-75-1

Web Jurnal Online: jurnal.unmuhjember.ac.id

By: Syafhendry; Setyo Utomo

Transformational Leadership In The Middle Of Plurality And Global Challenges

\section{Reference}

1. Bass, Bernard M, dan Riggio, Ronald E. 2005. "Transformasional Leadership, Learning and Employability".

2. C. W. Watson, 2000. "Muliculturalism". Buckingham: Open University Press

3. Hartiti. Tri (2013). "Efektifitas Model Kepemimpinan Transformasional terhadap Peningkatan Soft Skill Perawat Pelaksana”. Jurnal Disertasi Doktoral Keperawatan Universitas Indonesia

4. Kendra, Cherry (2013), "What is Transformational Leadership? How Transformasional Leadership Inspire”. About.com Guide, Retrieved Sep $25^{\text {th }} 2013$ from http://psychology.about.com/od/leadership/a/transformational.htm

5. PMcounseling (2011). "Sharing Innovative Business Research and Practices What is Transformational Leadership", retrieved Sep 25 ${ }^{\text {th }} 2013$, Fromhttp://pmcounseling.wordpress.com/2011/12/17/transformationalleadership/

6. Swandari, Fifi, 2003. "Menjadi Perusahaan Yang Survive Dengan

Transformasional Leadership”. Jurnal Ekonomi, Manajemen dan Akuntansi, Vol. 1 No. 2 Mei 2003:93-102 